\title{
Preparation Measurements and Assessment of Roof Systems
}

\author{
Richard Baláž, Miloslav Bagoňa \\ Technical University of Košice \\ Civil Engineering Faculty, Institute of Architectural Engineering, Department of Architectural Engineering \\ e-mail: richard.balaz@tuke.sk,miloslav.bagona@tuke.sk
}

\begin{abstract}
The Institute of Architectural Engineering at the Civil Engineering Faculty TU of Kosice, in its ongoing research, aims to monitor the physical properties of building envelope structures with emphasis placed on hydrothermal problems, at present. The research focuses on the assembly of equipment in climate chambers with their respective sample envelopes and fenestration systems, which are involved in a measuring experiment. The prime aim is to design a logical and transparent system for gathering, evaluating and storing hydrothermal related data. This contribution further illustrates the embedding system of measurement points in installed samples and the system of monitoring their physical properties over an annual period.
\end{abstract}

Key words: glass systems, buildings materials, roof in situ measurements, laboratory measurements, building envelope.

\section{Introduction}

A series of experimental measurements are currently underway, at the Institute of Architectural Engineering at the Civil Engineering Faculty TU of Kosice, that reflect the trends of current building practice, with a substantial share of research being devoted to prospective building materials and construction processes for potential future applications. The above mentioned institute recently obtained a grant for building an experimental research laboratory that consists of a series of macro "walk-in" test chambers which may be specifically utilized for conducting experiments based on the performance of fenestration systems.

\section{On site measurements}

Test chambers measure $4200 \times 2440 \times 2830(\mathrm{~mm})$ and include exposed interfaces for installing material samples and structural elements. The other walls, floor and ceiling are insulated with polyurethane insulation with a thickness of $150(\mathrm{~mm})$. The thermal resistance 
of these structures measures $\mathrm{R}=3\left(\left(\mathrm{~m}^{2} . \mathrm{K}\right) / \mathrm{W}\right)$. Samples subjected to monitoring of selected physical properties are embedded in the open interface of the climate chambers. The openings measure $1690 \times 2200(\mathrm{~mm})$ and include a supporting frame which is designed so that various peripheral structures - masonry, prefabricated, monolithic and transparent may be installed with minimum effort [1]. A monolithic concrete interface was chosen for the first two chambers (where the PVC windows were installed). Situation of test chambers measure is showed in Fig. 1.

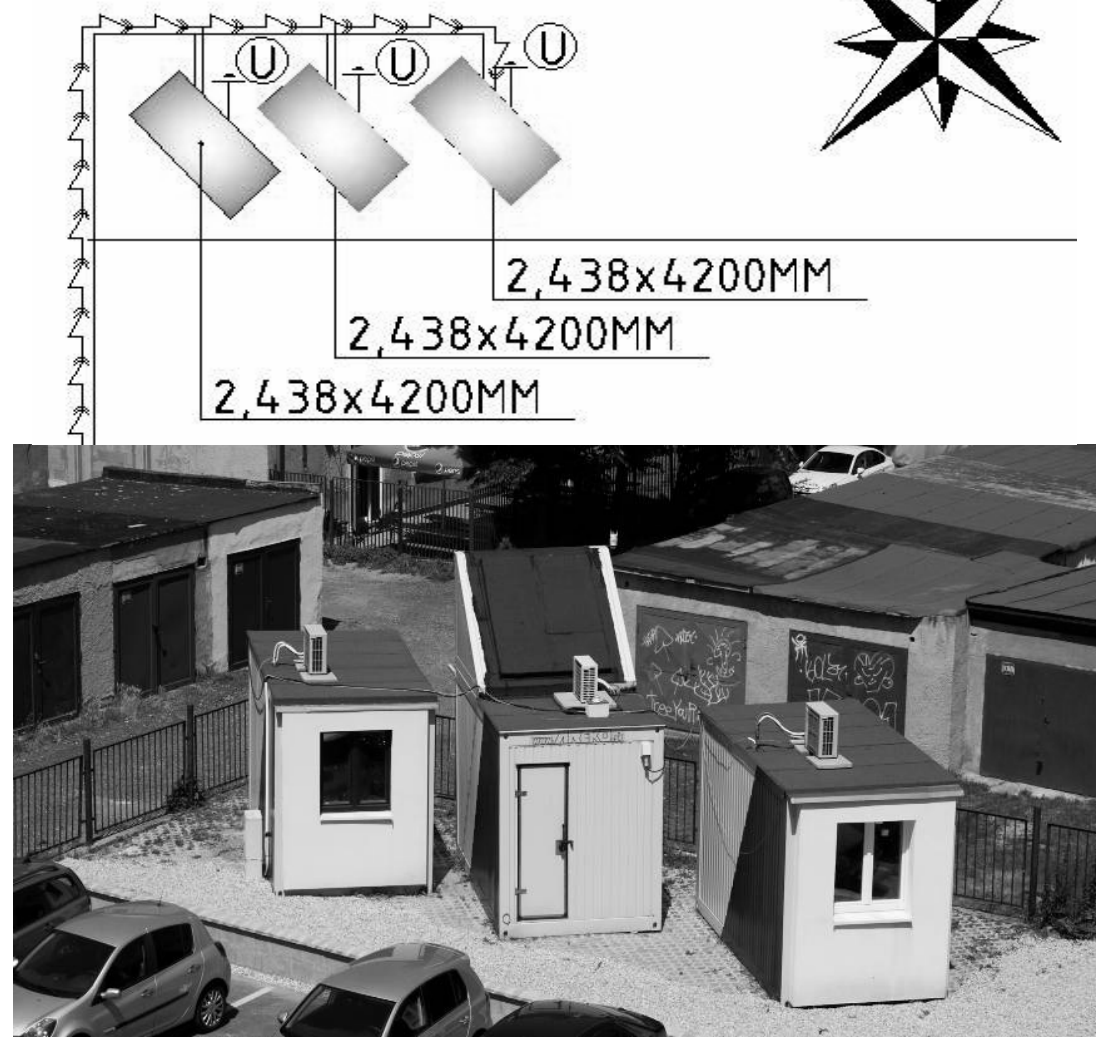

Figure 1: Situation of test chambers measure

\section{Implementation panel}

The experimental chambers are differentiated by the cardinal orientation of the openings which allows the performance of the building envelope to be monitored from a north and south orientation respectively [2].

Chamber no. 1 and 2 are identical in construction but differ in the orientation of the monitored panels - specifically for comparing physical properties when exposed to the north, and south Chamber no. 3 and roof module no.1 are orientated due south. Fenestration systems (windows) are installed in elements of the envelope construction. Samples of envelope structures are the object of measuring: 
- Chamber 1 and 2 - consists of two masonry structures divided vertically - Autoclaved aerated concrete YTONG LAMBDA-P2 350 PDK and polished ceramic brick blocks HELUZ STI 30. The whole structure is insulated with graphite polystyrene - facade insulation board GreyWall 033 and a plaster rendering system using CERESIT. These test chambers is showed in Fig. 2.

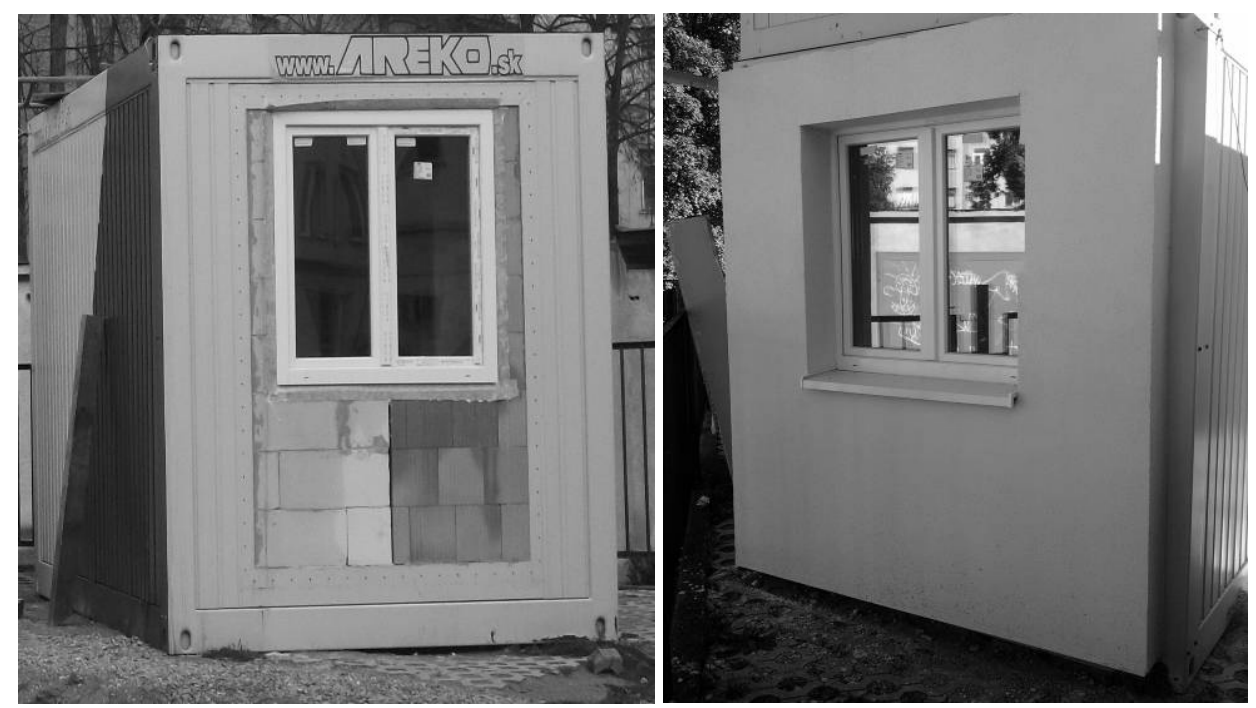

Figure 2: Chamber no. 1 and 2

- Chamber 3 - wood particle board construction with thermal insulation - The inside surface consists of mineral insulation from Isover fiberglass - UNIROL PROFI covered with particle board - facade insulation board consists of longitudinal fibred ISOVER TF 100 insulation covered with a CERESIT plaster rendering system. Test chamber no. 3 is showed in Fig. 3.
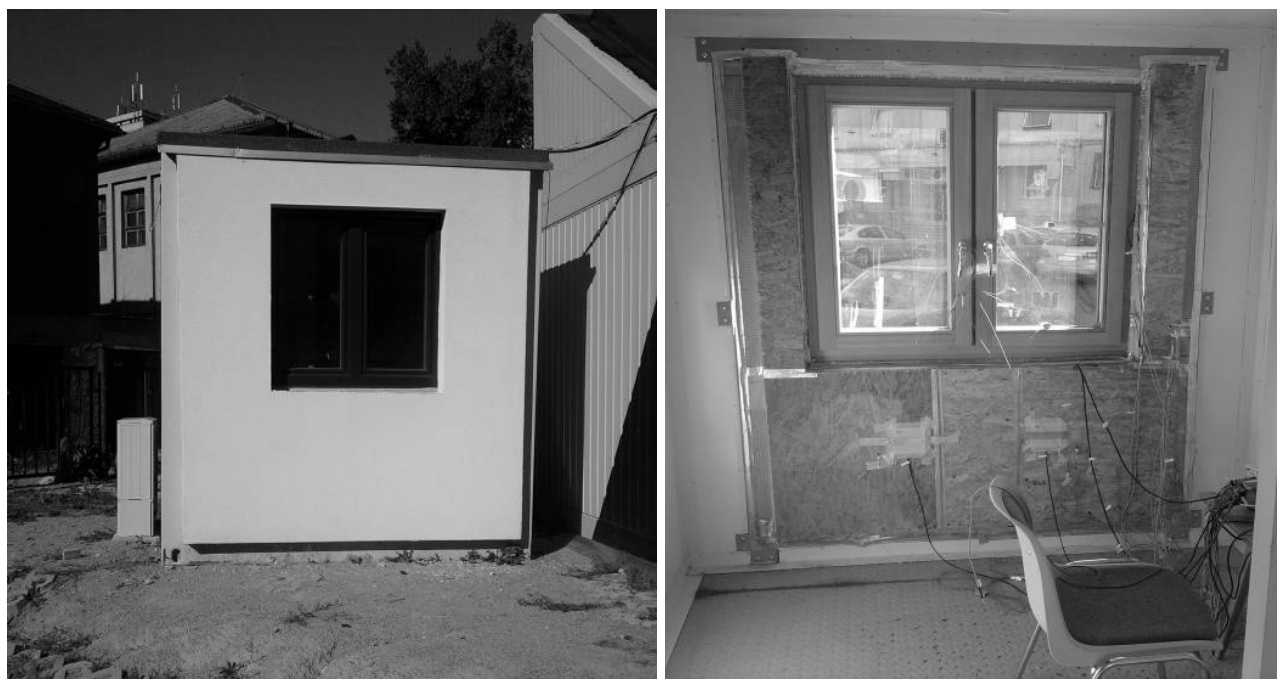

Figure 3: Chamber no.3 
- Roof module in chamber no. 2 - timber frame construction filled with OSB particle boards. One side uses a vapour barrier while the other side omits the use of a vapour barrier; both using thermal insulation by ISOVER UNIRE-PRO. Roofing skin consists of asphalt strips filled with THERMOABASE thermal insulation. The ceiling is finished with dry walling. Roof module is showed in Fig. 4.
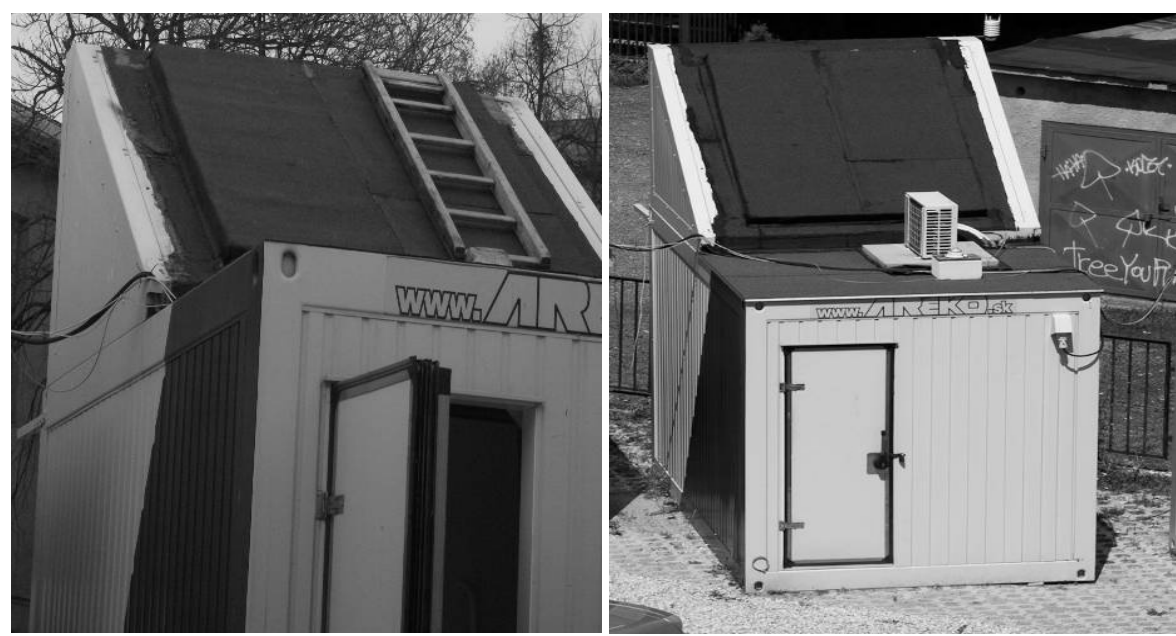

Figure 4: Chamber no. 2 - roof structure and roof element

- Window construction - openings structures for chambers no.1 and no.2, integrates a double-wing tilt \& turn window, the profile consists of composite plastic material REHAU GENEO MD plus the window is triple glazed with insulating 4-12-4-12-4 from the company NITRASKLO.

- Window construction - filling chamber no.3 opening structure, which consists of a double-wing tilt \& turn window Internorm EDITION box with a wood-aluminium profile frame of high insulation integrating thermal foam in the aluminium cavities. The window is triple glazed with insulating $\mathrm{Cr}$ 4-16-4-16-4 from the company, NITRASKLO.

\section{Instruments}

A necessary step to avoid the ambiguous evaluation of measured data requires the labelling of individual sensors, measurement units and related equipment for integration and other applications. A system that applied the use of colour coding was applied and includes numbers and numerals for further clarification of the measured physical properties. Four categories were classified according to the criteria of the individual sensors:

- Temperature sensors with different characteristics,

- Humidity sensors,

- Sensors to measure other quantities,

- Meteo-station 
The system allows for the addition of new equipment, while maintaining alphabetical order, because letters were omitted in each category of measurement data. Alphabetical letters ensure the exact type and designation of each sensor connector. Measured parameters such as temperature and relative humidity of the outside and indoor air, as well as the temperature and relative humidity inside the structure, were conducted its surface temperature and heat flux. Temperature sensors use resistance tips made of Ntc and NiCr. A VAISALA meteostation measures wind direction, and the average maximum wind speed, atmospheric pressure, temperature and relative humidity of the outside air, the amount and intensity of precipitation as well as global, and sky shortwave radiation [3].

\section{Preparation and production of measuring samples of roof cladding}

The configuration of the roof skin was the result of a detailed analysis featured in (Fig. 5). Because the roof model, measuring $1700 \mathrm{~mm}$ x $2200 \mathrm{~mm}$ lacked a Centre support, 2 pieces of identical roof panels had to overlap the module so as to create two distinct parts (showed in Fig. 6). The structures of the two roof elements differ. The right side of the module is equipped with thermal insulation manufactured by Nobasil with a vapour barrier from a JUTAFOL N; the drywall ceiling is anchored to the support above using a "U" profile. The left side is equipped with Nobasil $125 \mathrm{~mm}$ thermal insulation, but excludes a vapour barrier while the drywall ceiling is similarly anchored as the one on the right side. Surface ceiling is without finishing treatment. The roof module with dimensions of $1700 \mathrm{~mm} \times 2200 \mathrm{~mm}$ was supported and separated by a $125 \mathrm{~mm} \times 125 \mathrm{~mm}$ wooden beam with the known thermotechnical properties [4].

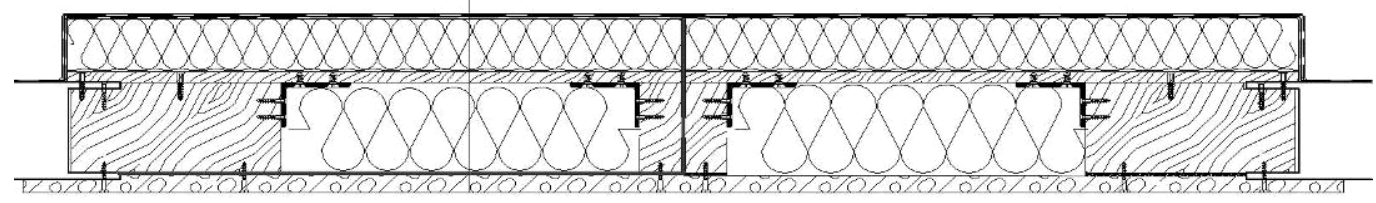

Figure 5: Sample of roof covering
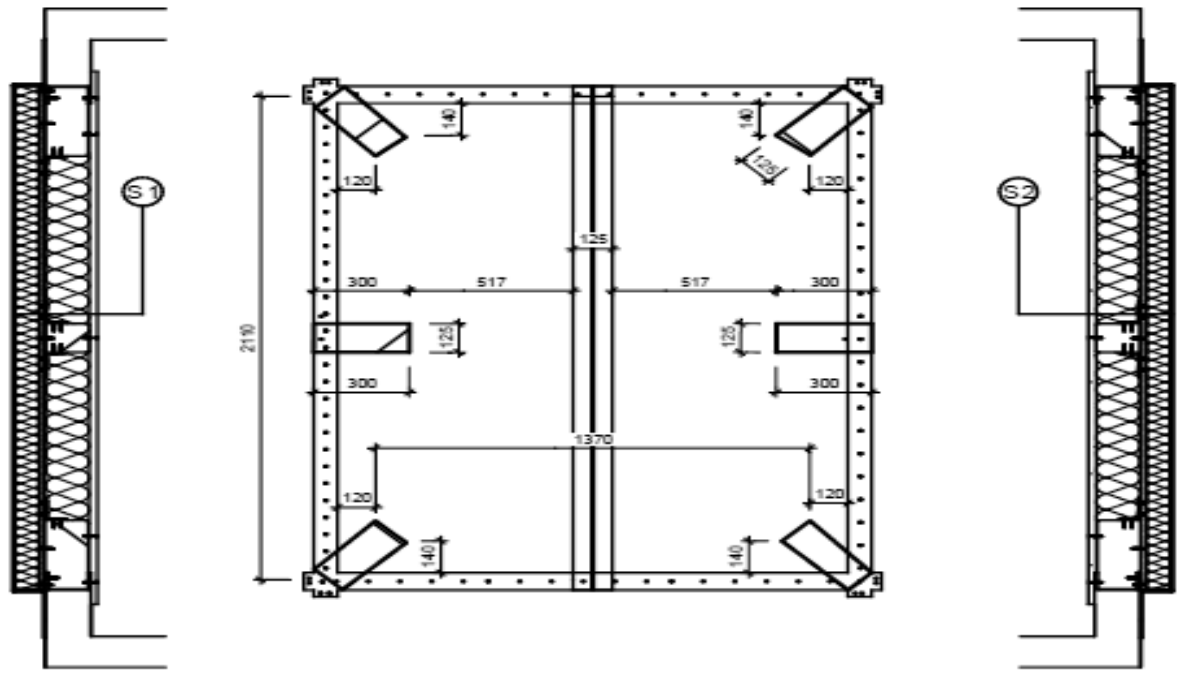

Figure 6: Sample of roof covering 
The wooden beam was cut through the middle Axis and did not have JUTAFOL $N$ vapour barrier placed in the gap. Sample roof deck above the rafters will be the same the two halves of the roof module was made and then fitted into the roof module and will consist of the following compositions: OSB with increased load thickness of $15 \mathrm{~mm}$ is attached to the top of the rafter. As second layer Prominent layer is anchoring (with micro-ventilation for polyurethane insulation). As the end of the bottom and the top is used metal edging (made on the site of galvanized sheet thickness $2 \mathrm{~mm}$ ). Attached to the OSB and then affixed anchoring layer Prominent. The following panel is modified by a gas burner snapping insulation Thermobase (polyurethane thermal insulation the top layer of cardboard) thickness $80 \mathrm{~mm}$ so manufactured roof panels were fitted into the roof module. As last layer is applied bitumen from the company board index mineral thickness of $4.5 \mathrm{~mm}$ brown colour overlay to the overall roof structure [4].

\section{Distribution and type of sensor in the test sample roof cover}

The construction in the roof research module was divided into construction S1 and construction S2. S1 contains a vapour barrier Jutafol N in contrast to S2. Sensors in the roof construction sample were positioned in individual layers of the roof element, mirroring each other at $300 \mathrm{~mm}$ from the center line defined by a load bearing beam. The first temperature sensor was mounted closest to the exterior underneath the bitumen layer of S1 A37 as with S2 sensor A3.8, the second layer of the roof cover consists of thermal insulation (polyurethane) with a sensor A3.9 and A3.10 placed in the center line of the insulation i.e. $40 \mathrm{~mm}$. The third layer of the roof cover consists of a connection layer which placed on OSB particle board. They house sensors A3.11 and A3.12.Sensors A3.7, A3.8, A3.9, A3.10, A3.11 and A3.12 are temperature sensors based on the resistance without a tip with capabilities of $-50-125^{\circ} \mathrm{C}$. Internal insulation consists of mineral wool $125 \mathrm{~mm}$ thick where a sensor I1/6 was placed at its center which mirrors $\mathrm{v} I 1 / 2$. These sensors measure air temperature, relative humidity, dew point and absolute humidity and finally sensors D1/13 and D1/14. These were positioned on the internal drywall on the interior surface. This sensor measures the surface temperature at two points [5]. Measurement of heat transfer coefficient " $U$ " of roof structure.

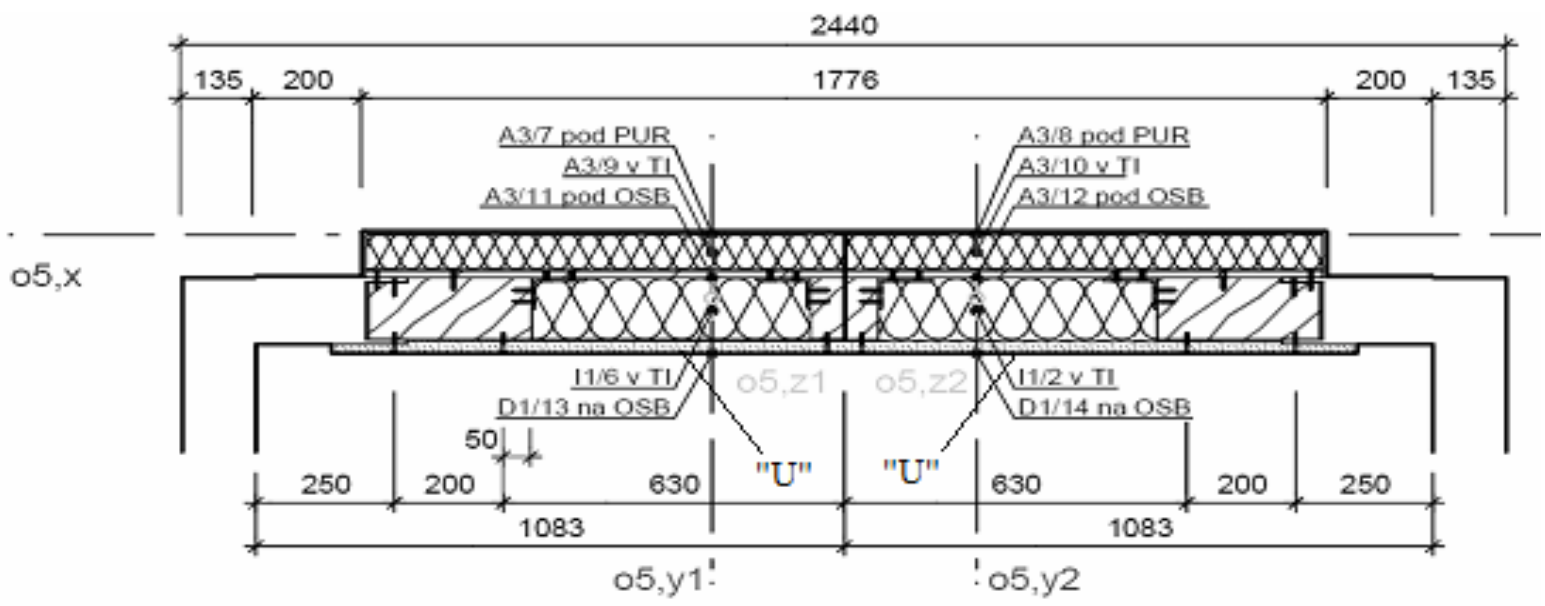

Figure 7: The deployment of sensors 
Measured parameters are outside and inside air temperature and relative humidity, temperature and relative humidity inside the structure, surface temperature and heat flux. For those purposes is used temperature sensors based on resistance without nib, type NTC and $\mathrm{NiCr}$ (Fig. 7). Weather station measure wind direction, average and maximum wind speed, atmospheric pressure, air temperature and relative humidity, rainfall and we also monitor global radiation by Pyranometer Chyba! Nenalezen zdroj odkazů., [6], [6].

\section{The measurement of physical and technical parameters}

\section{Measurement of heat transfer coefficient " $U$ " of roof structure}

Winter pre-test measurements of heat insulation properties and structures factors were the subject of the tests. The first measurements involved the heat transfer coefficient structure (Uvalue). These measurements were made with a measuring device Testo 635 with the probe to determine the U-value (heat transfer coefficient) and then compared with the calculation. A total of 6 measurements were made with 4 measurements made every 15 minutes, and two measurements at 60 minute intervals, all conducted under different ambient temperatures, (the difference of internal and external temperatures was a min. $20^{\circ} \mathrm{C}$ ). Table 1 lists the measured values compared to calculated values.

Table 1: Comparison of calculated and measured values of heat transfer coefficient

\begin{tabular}{|c|c|c|}
\hline \multicolumn{2}{|c|}{ Measurement } & Calculated value \\
\cline { 1 - 1 } 1 & $0,1785 \mathrm{~W} /\left(\mathrm{m}^{2} \mathrm{~K}\right)$ & \multirow{2}{*}{} \\
\cline { 1 - 1 } 2 & $0,1797 \mathrm{~W} /\left(\mathrm{m}^{2} \mathrm{~K}\right)$ & \multirow{2}{*}{$0,17 \mathrm{~W} /\left(\mathrm{m}^{2} \mathrm{~K}\right)$} \\
\cline { 1 - 1 } 3 & $0,1800 \mathrm{~W} /\left(\mathrm{m}^{2} \mathrm{~K}\right)$ & \\
\cline { 1 - 1 } 4 & $0,1828 \mathrm{~W} /\left(\mathrm{m}^{2} \mathrm{~K}\right)$ & \\
\cline { 1 - 1 } 5 & $0,1800 \mathrm{~W} /\left(\mathrm{m}^{2} \mathrm{~K}\right)$ & \\
\cline { 1 - 1 } & $0,1821 \mathrm{~W} /\left(\mathrm{m}^{2} \mathrm{~K}\right)$ & \\
\hline & $0,1805 \mathrm{~W} /\left(\mathrm{m}^{2} \mathrm{~K}\right)$ & $0,17 \mathrm{~W} /\left(\mathrm{m}^{2} \mathrm{~K}\right)$ \\
\hline
\end{tabular}

Measured sample roof coating structures S1 and S2 in the climatic chamber module is no sign of improper design, non-working practices in the construction and the measurement itself has taken place in compliance with all procedures specified by the manufacturer and this it can be concluded that the difference in measured and calculated values of heat transfer coefficient is $0,0105 \mathrm{~W} /\left(\mathrm{m}^{2} \mathrm{~K}\right)$. This difference may arise:

- measuring device Testo 365 is measured with an accuracy of $\pm 0,005 \mathrm{~W} /\left(\mathrm{m}^{2} \mathrm{~K}\right)$,

- measuring probe for measuring the heat transfer coefficient with an accuracy of \pm $0,003 \mathrm{~W} /\left(\mathrm{m}^{2} \mathrm{~K}\right)$,

- in the actual values averaged values were calculated to three digits after the point $(0,000)$. 
Roof construction S1 and S2 shows almost identical data in the calculated value of heat transfer coefficient and the actual measured value of heat transfer coefficient structure.

Measurement of internal and surface temperatures in the construction of roof coating module in a climatic chamber

Winter pre-test measurements of heat insulation properties and structures factors were the subject of the tests. These measurements were logged and measured using sensors described above. It is important to note that these measurements were conducted under steady-state temperature of the internal environment and changing the state of the climate conditions. A constant temperature of $20^{\circ} \mathrm{C}$ is maintained in the interior of the climatic chamber. Measurements were carried out in individual layers:

- Measurement no.1 was made on the surface of the insulating layer (damp proof membrane) structures S1 and S2.

- Measurement no.2 consists of the measurement of the internal temperature in the polyurethane thermal insulation in the roof structure S1 and S2.

- No.3 measurement was made on the surface of OSB roof structure S1 and S2.

- Measurement no.4 consists of measuring the internal temperature of rock wool structures $\mathrm{S} 1$ and $\mathrm{S} 2$.

- Measurement no.5 drawn on the surface of gypsum ceiling module in the climatic chamber, the sample design S1a S2.

Table 2: Overall comparison of measurements 1 to 5

\begin{tabular}{|c|c|c|}
\hline \multicolumn{2}{|r|}{ Measurement } & $\begin{array}{l}\text { The average value of the } \\
\text { temperature difference in the } \\
\text { roof structure S1 and S2 }\end{array}$ \\
\hline 1. & $\begin{array}{l}\text { Measurement was made on the surface of the } \\
\text { insulating layer (damp proof membrane) } \\
\text { structures S1 and S2. }\end{array}$ & $0,036^{\circ} \mathrm{C}$ \\
\hline 2. & $\begin{array}{l}\text { Measurement consists of the measurement of the } \\
\text { internal temperature in the polyurethane thermal } \\
\text { insulation in the roof structure S1 and S2. }\end{array}$ & $0,0663{ }^{\circ} \mathrm{C}$ \\
\hline 3. & $\begin{array}{l}\text { Measurement was made on the surface of OSB } \\
\text { roof structure S1 and S2. }\end{array}$ & $0,2803^{\circ} \mathrm{C}$ \\
\hline 4. & $\begin{array}{l}\text { Measurement consists of measuring the internal } \\
\text { temperature of rock wool structures S1 and S2. }\end{array}$ & $0,2777^{\circ} \mathrm{C}$ \\
\hline 5. & $\begin{array}{l}\text { Measurement drawn on the surface of gypsum } \\
\text { ceiling module in the climatic chamber, the } \\
\text { sample design S1a S2. }\end{array}$ & $0,0505^{\circ} \mathrm{C}$ \\
\hline \multicolumn{2}{|r|}{$\begin{array}{l}\text { The overall average temperature difference in the } \\
\text { construction of S1 and S2. }\end{array}$} & $0,165^{\circ} \mathrm{C}$ \\
\hline
\end{tabular}

The roof structure S1 (roof deck construction incorporates a vapour barrier) in the quasistationary thermal-moisture state of the internal environment under conditions of climate change environmental factors in situ reported to the roof structure S2 (structural roof deck 
where it is applied vapour barrier) in the quasi-stationary thermal -humidified state of the internal environment in terms of climate change environmental factors in situ difference of internal and surface temperatures on average $0,165^{\circ} \mathrm{C}$. The measurement results 1 to 5 shown in Table 2.

Phase shift of temperature oscillation in the roof structure S1 and S2 in the quasi-steady state of the internal environment and the changing external environment

Comparison of the phase of the temperature oscillation was assessed in the months October 2012, November 2012, January 2013 and February 2013. For the calculation itself is to be noted that as the inner surface temperature was used value from the sensor $\mathrm{D} / 13$ to construct sensor S1 and S2 D/14 for design. / Sensor measuring the surface temperature of the plasterboard /. In individual months were selected values of minimum and maximum outdoor temperature with their associated values of surface temperature in the roof structure and roof structure S1 and S2 they were subsequently compared.

A full assessment of the phase shift of the temperature oscillation in the construction of the roof shell S1 and S2 shown in Table 3.

Graph 1. Day phase shift for winter period

November/day/

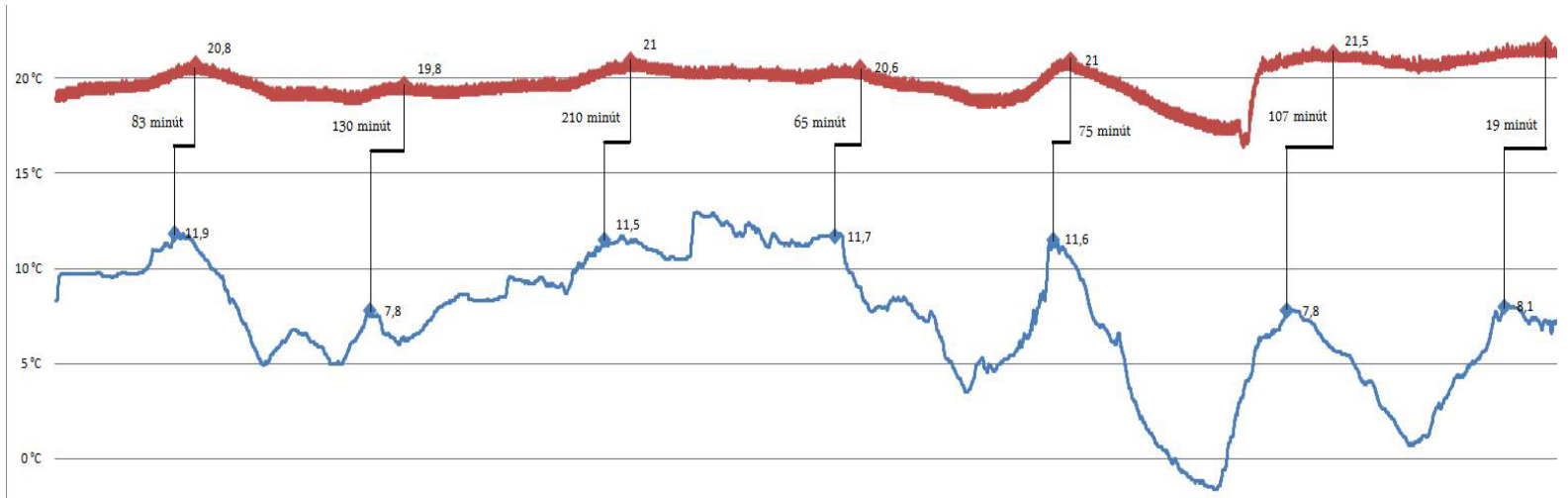

Blue graph-external temperature, red graph - surface temperature on Drywall roof S2

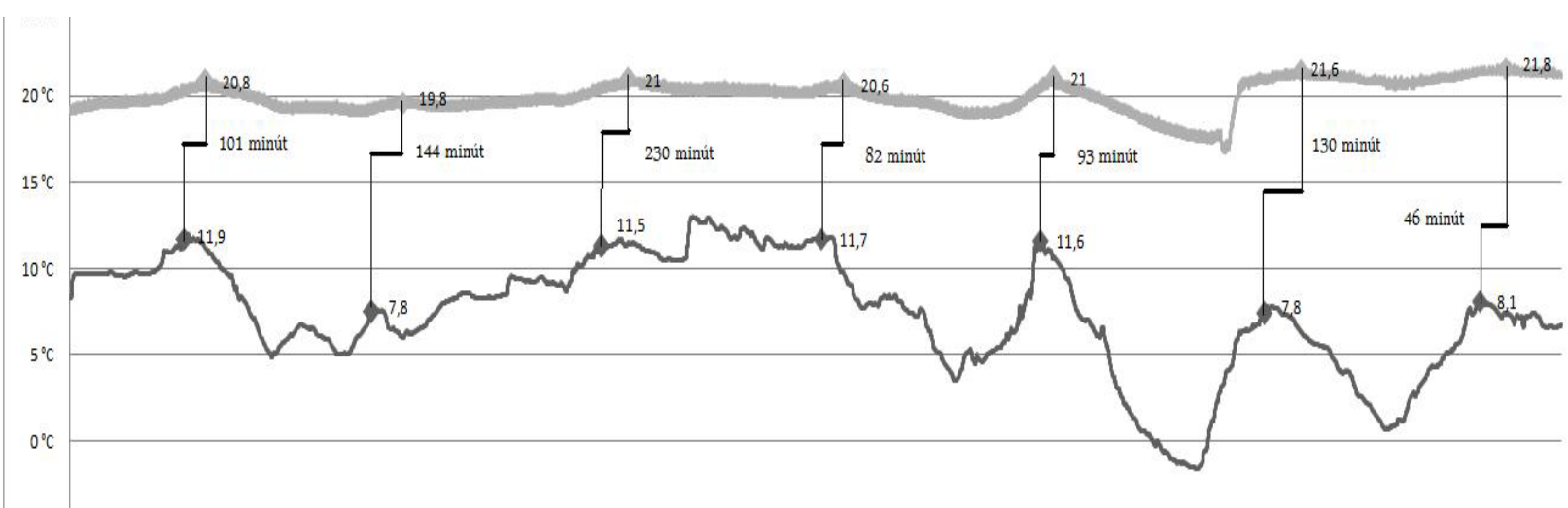

Brown graph-external temperature, gray graph - surface temperature on Drywall roof S1 
Graph 2. Day phase shift for winter period January /day/

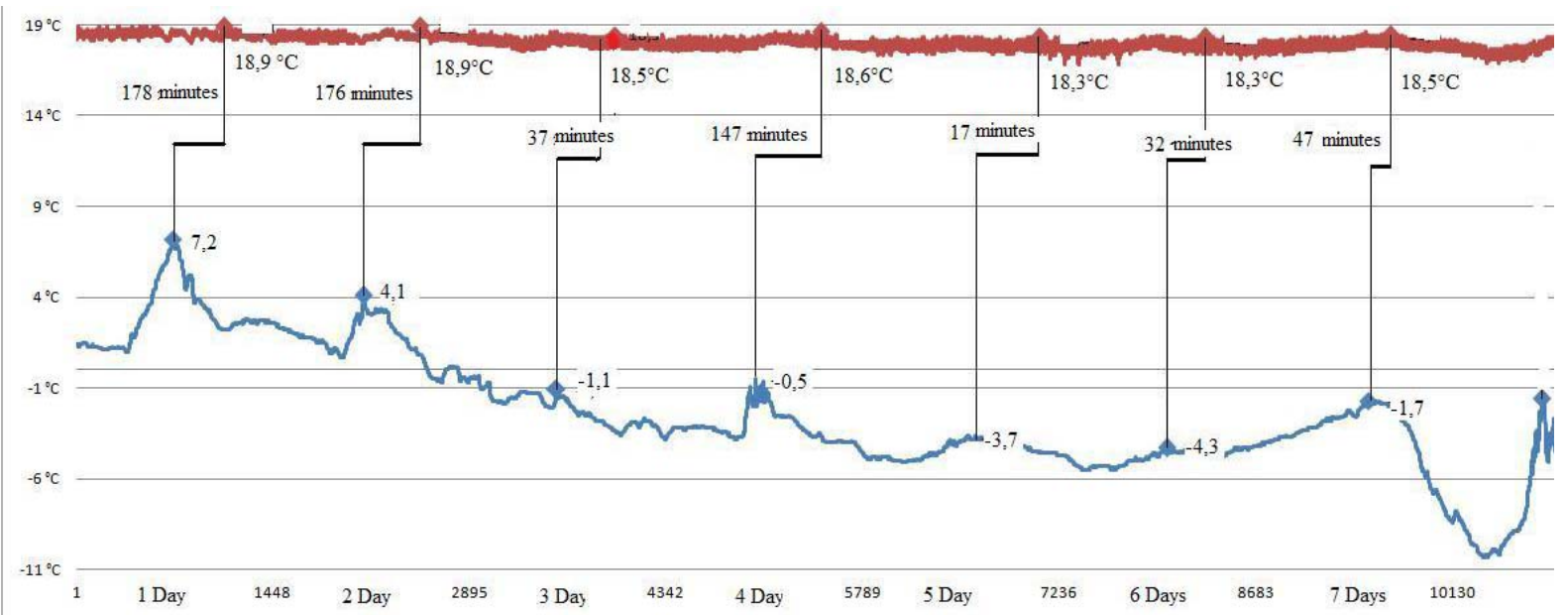

Blue graph-external temperature, red graph - surface temperature on Drywall roof S2

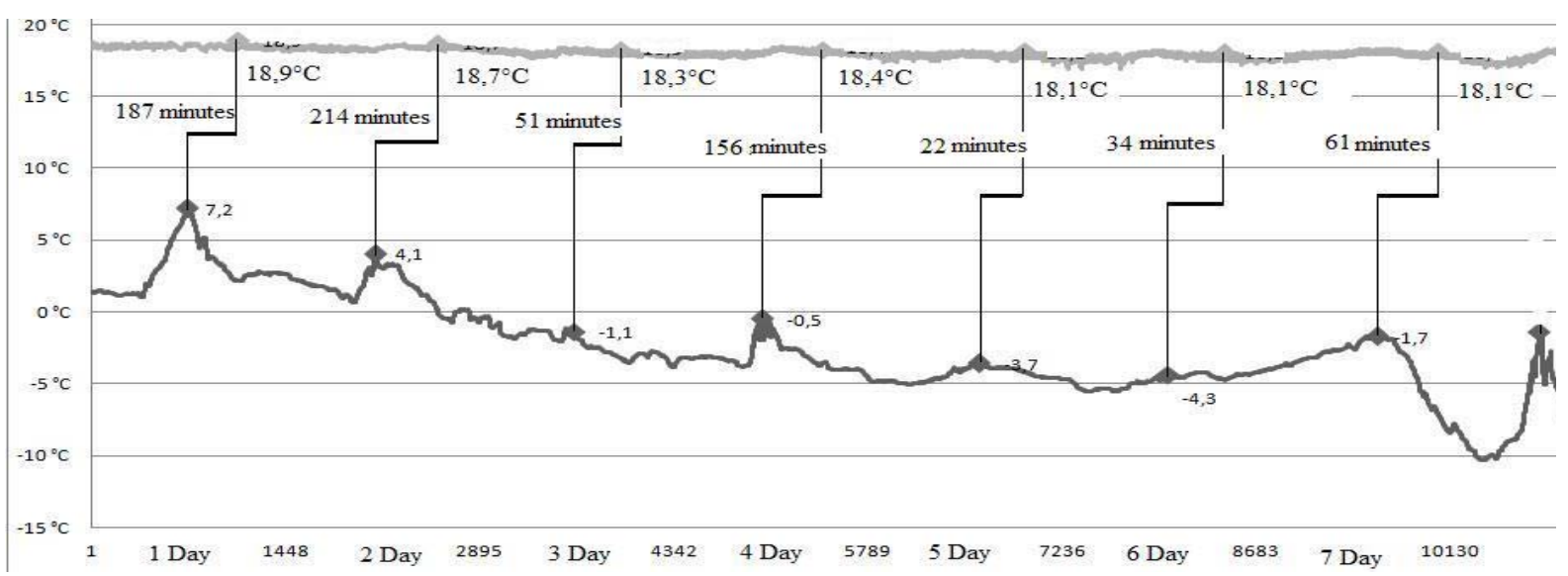

Brown graph-external temperature, grey graph - surface temperature on Drywall roof S1

Table 3: Overall comparison of temperature oscillation phase shift structure S1a S2

\begin{tabular}{|c|c|c|c|}
\hline \multicolumn{2}{|c|}{} & $\begin{array}{c}\text { The roof } \\
\text { structure S1 }\end{array}$ & $\begin{array}{c}\text { The roof } \\
\text { structure S2 }\end{array}$ \\
\hline \multirow{4}{*}{$\begin{array}{c}\text { Daily } \\
\text { temperature } \\
\text { Oscillation } \\
\text { phase shift for } \\
\text { the winter } \\
\text { season }\end{array}$} & October & $\begin{array}{c}\psi=81,59 \\
\text { minutes }\end{array}$ & $\begin{array}{c}\psi=81,55 \\
\text { minutes }\end{array}$ \\
\cline { 2 - 4 } & November & $\begin{array}{c}\psi=118 \\
\text { minutes }\end{array}$ & $\begin{array}{c}\psi=98,42 \\
\text { minutes }\end{array}$ \\
\cline { 2 - 4 } & January & $\begin{array}{c}\psi=104 \\
\text { minutes }\end{array}$ & $\begin{array}{c}\psi=88,66 \\
\text { minutes } \\
\text { minutes }\end{array}$ \\
\cline { 2 - 4 } & February & $\begin{array}{c}\psi=133,85 \\
\text { minutes }\end{array}$ & $\begin{array}{c}\psi=90,57 \\
\text { minutes }\end{array}$ \\
minutes \\
\hline
\end{tabular}




\begin{tabular}{|c|c|c|c|}
\hline \multicolumn{2}{|c|}{ The average value } & $\begin{array}{c}\psi=108,202 \\
\text { minutes }\end{array}$ & $\begin{array}{c}\psi=96,782 \\
\text { minutes }\end{array}$ \\
\hline \multicolumn{2}{|c|}{ Difference } & \multicolumn{2}{|c|}{$\psi=11,42$ minutes } \\
\hline & & $\begin{array}{c}\text { The roof } \\
\text { structure S1 }\end{array}$ & $\begin{array}{c}\text { The roof } \\
\text { structure S2 }\end{array}$ \\
\hline \multirow{5}{*}{$\begin{array}{l}\text { Night } \\
\text { temperature } \\
\text { oscillation } \\
\text { phase shift for } \\
\text { the winter } \\
\text { season }\end{array}$} & October & & \\
\hline & November & $\begin{array}{l}\psi=91,4 \\
\text { minutes }\end{array}$ & $\begin{array}{c}\psi=\overline{7} 6,57 \\
\text { minutes }\end{array}$ \\
\hline & December & $\begin{array}{l}\psi=139 \\
\text { minutes }\end{array}$ & $\begin{array}{l}\psi=121,3 \\
\text { minutes }\end{array}$ \\
\hline & January & $\begin{array}{l}\psi=133 \\
\text { minutes }\end{array}$ & $\begin{array}{c}\psi=116,4 \\
\text { minutes }\end{array}$ \\
\hline & February & $\begin{array}{c}\psi=61 \\
\text { minutes }\end{array}$ & $\begin{array}{c}\psi=48,57 \\
\text { minutes }\end{array}$ \\
\hline \multicolumn{2}{|c|}{ The average value } & $\begin{array}{l}\psi=106,1 \\
\text { minutes }\end{array}$ & $\begin{array}{c}\psi=90,71 \\
\text { minutes }\end{array}$ \\
\hline
\end{tabular}

\section{Conclusion}

A series of experimental measurements are currently underway, at the Institute of Architectural Engineering at the Civil Engineering Faculty TU of Kosice, that reflect the trends of current building practice, with a substantial share of research being devoted to prospective building materials and construction processes for potential future applications. The above mentioned institute recently obtained a grant for building an experimental research laboratory that consists of a series of macro "walk-in" test chambers which may be specifically utilized for conducting experiments based on the performance of fenestration systems and roof systems. The prime aim is to design a logical and transparent system for gathering, evaluating and storing hygrothermal related data.

The thesis focuses on the assessment of thermo-dynamic parameters of S1 and S2 roof structures in a climatic chamber. The experimental measurements performed on the sloped roof were evaluated by comparing four thermal parameters. The first was the measurement of the coefficient of heat flux, followed by internal and external surface temperatures in different layers of the roof structure. The phase change for winter conditions was deduced from the external and internal temperatures and compared with the actual and calculated values of the surface temperatures. From the experimental measurements it can be concluded that the structure S1 has better thermal properties than structure S2. It is important to note that the experimental measurements were carried out for the quasi-stationary states so that the internal environment remained stable and the external parameters fluctuated.

From the comparison of test measurements in a climatic chamber module for quasi-stationary conditions for the internal structures S1 and S2 structures it can be stated that the vapour barrier in the construction JUTAFOL N S1 had an impact on the roof structure in terms of the phase shift of the temperature oscillation as follows: 
- The roof structure S1 with a vapour barrier JUTAFOL N shows that a phase shift daily temperature oscillation in the winter was 11.42 (minutes) more favourable than the roof structure without the use of a vapour barrier (S2). These measurements were conducted as a quasi-stationary state of the internal environment in a climatic chamber.

- The roof structure S1 vapor barrier with Jutafol N shows that nightly a phase shift of the temperature oscillation in the winter is 15.39 (minutes) more favourable than the roof structure without the use of a vapour barrier ( S2 ). These measurements were conducted as a quasi- stationary state of the internal environment in a climatic chamber.

\section{Acknowledgements}

This paper was created thanks to financial support from the EU Structural Funds, through the Operational Program R \& D and project OPVaV-2008/2.2/01-SORO "Architectural, engineering, technological and economic aspects of the design of energy efficient buildings, codenamed ITMS: 26220220050; which is financed by EC funds.

\section{References}

[1] Straube, J. (2006). Building Science Digest 005. Green Building and Sustainability, October 2006. Building Science Press.

[2] Katunský, D. (2009). Skúšobné zariadenie pre výskum obalových konštrukcií inteligentných budov. Inovatívny prístup k modelovaniu inteligentných konštrukčných prvkov v stavebníctve, ZVPVÚIS Košice, XII/200. pp. 33-42.

[3] Katunský, D. at al. (2011). Centrum excelentného výskumu progresívnych stavebných konštrukcií a indoor technológií na Ústave budov a prostredia. Ústav budov a prostredia, Stavebná fakulta, Technická univerzita v Košiciach. pp. 8-13.

[4] Baláž, R., Bagoňa, M. (2012). Návrh a príprava strešnej vzorky do modulu klimatickej komory. Poruchy a obnova obalových konštrukcií budov. 12: zborník príspevkov z konferencie $\mathrm{s}$ medzinárodnou účast'ou. pp. 357-361.

[5] Ahlborn, Almemo. (2009). Manual - Fundamentals of measuring technology, Sensors programming, $8^{\text {th }}$ revised edition.

[6] CHUCHMA, L., KALOUSEK, M.. (2014). Electricity storage in passive house in Central Europe region. Advanced Materials Research, Vol. 2014,Issue. 899, pp. 213-217.

[7] Feist W. (2009). Passivhausstandard-konkrete Losung für eine globale Aufgabe, Universität Innsbruck und Passivhaus Institut, Proceeding Pasívne domy 2009.

[8] Flimel M. (2013). Differences Ug - values of glazing measured in situ with the influence factors of the internal environment, 2013, In: Advanced Materials research. Vol. 649, pp. 61 - 64 . 